\title{
A revised position for the rotated Falkland Islands microplate
}

\author{
Roxana M. Stanca ${ }^{*}$, Douglas A. Paton ${ }^{1}$, David M. Hodgson ${ }^{1}$, Dave J. McCarthy² \& Estelle J. \\ Mortimer $^{1}$ \\ ${ }^{1}$ School of Earth and Environment, University of Leeds, Leeds LS2 9JT, United Kingdom \\ ${ }^{2}$ Lyell Centre, British Geological Survey, Edinburgh EH14 4AP, United Kingdom \\ *Corresponding author (e-mail: r.m.stanca@leeds.ac.uk)
}

\begin{abstract}
The early stages of transform margin formation are associated with crustal fragmentation and block rotation. The restricted size of the resultant microcontinental blocks precludes palaeogeographic reconstructions and reliable estimations of the amount of rotation they can undergo. An example considered here is the Falkland Plateau. This is located adjacent to the Agulhas-Falkland Fracture Zone/Transform and its westernmost province is the Falkland Islands microcontinent. The position of the plateau and the islands prior to Gondwana break-up remains contentious. This study integrates seismic reflection and gravity data to propose a revised position of the Falkland Islands microcontinent constrained by: (a) the presence of a mega-décollement, controlling the Gondwanide Orogen, described north of the Falkland Islands and underneath South Africa and Outeniqua Basin, and (b) the similar architecture of fault networks mapped north of the islands and in the northernmost Outeniqua Basin. This revised position requires a re-evaluation of the timing and rate of rotation of the Falkland Islands microcontinent and impacts the expected crustal architecture adjacent to the islands. Our model yields rotation rates between $5.5^{\circ}$ and $8^{\circ} \mathrm{Myr}^{-1}$, two potential times for rotation and predicts more unstretched crust beneath the basin east of the Falkland Islands than previous models.
\end{abstract}


Transform margins are associated with a complicated tectono-stratigraphy (Scrutton 1979; Basile \& Allemand 2002; Mercier de Lépinay et al. 2016) and a unified model for their evolution is yet to be established. Commonly, their incipient development stages can be associated with crustal fragmentation and block rotation (Mascle \& Blarez 1987). Typically, the resultant microcontinental blocks have a limited outcrop extent. This paucity of information hinders palaeogeographic reconstructions of these blocks which are crucial for understanding the prebreak-up configuration of transform margins. A more reliably constrained palaeoposition of the transform-related microcontinental blocks can also bring insights into the amount of rotation that can affect these blocks and also on the architecture of the continental crust adjacent to them.

A pertinent example considered here is the Falkland Plateau transform margin (Fig. 1). Its position prior to Gondwana break-up is highly dependent on the position of the Falkland Islands microcontinent.

Reaching a consensus on reconstructions of the southern Gondwanan margin prior to the opening of the South Atlantic Ocean has been hampered by conflicting models that try to account for the position and orientation of the Falkland Plateau. Palaeogeographic reconstructions of Gondwana during the Permo-Triassic recognize a Gondwanide fold and thrust belt that extended from South America through South Africa to Antarctica (Du Toit 1937; Trouw \& De Wit 1999; Dalziel et al. 2000). The first to recognize a link between this fold and thrust belt and the Falkland Islands was Du Toit (1927) while Adie (1952a) further argued for a positioning of the islands east of South Africa in a rotated position as an extension of the Cape Fold Belt. Subsequent studies (Mitchell et al. 1986; Marshall 1994; Mussett \& Taylor 1994; Curtis \& Hyam 1998; Thistlewood \& Randall 1998 in Stone 2016; Thomson 1998; Trewin et al. 2002) favoured this reconstruction but the associated uncertainties in interpretation and drawbacks of the model led also to the emergence of a rigid model (Richards et al. 1996; Lawrence et al. 1999; Ramos et al. 2017) with the islands and the Falkland Plateau fixed to the South American plate.

Extensive work has been carried across the Falkland Islands (Curtis \& Hyam 1998; Aldiss \& Edwards 1999) and their adjacent sedimentary basins (Ludwig et al. 1979; Lorenzo \& Mutter 1988; Platt \& Philip 1995; Richards et al. 1996; Richards \& Fannin 1997; Thomson 1998; Del Ben \& Mallardi 2004; Baristeas et al. 2013; Lohr \& Underhill 2015). However, deep crustal studies in the offshore region have not been equally widespread, being mainly focused on the Falkland Plateau Basin (Ewing et al. 1971; Lorenzo \& Mutter 1988; Lorenzo \& Wessel 1997; Schreider et al. 2011; Kimbell \& Richards 2008; Schimschal \& Jokat 2017). There is, nonetheless, a well constrained crustal model for the southern South African margin and its offshore basins (Dürrheim 1987; Hälbich 1993; Paton \& Underhill 2004; Paton et al. 2006). The offshore North Falkland Basin is well known only at the scale of its sedimentary infill. Therefore, a direct comparison between the Falkland Islands microplate and the southern South African margin, at a crustal scale, is hard to accomplish. This scarcity of information regarding the deep structure also precludes a more accurate positioning of the islands prior to the break-up of Gondwana.

In this study, we aim to integrate offshore seismic reflection and gravity data from the Southern North Falkland Basin (SNFB) to bring new insights into the crustal architecture of the Falkland Islands microplate and better constrain its palaeoposition. The specific objectives are as follows: (a) to map the major tectonic features across the North Falkland Basin, (b) to compare the structural architecture of the SNFB and the Outeniqua Basin offshore South Africa, (c) to constrain the pre-break-up position of the Falkland Islands, and (d) to discuss the implications of the results. 


\section{GEOLOGICAL BACKGROUND}

\section{General tectonic setting of south-western Gondwana}

The crustal evolution of the southern margin of Gondwana was characterised by repeated reactivation of older structural features in an extensional or compressional regime (Paton \& Underhill 2004). After passive margin conditions (1600-1200 Ma), compression ensued between 1200 and $900 \mathrm{Ma}$ (Hälbich 1993; Thomas et al. 1993). This was accompanied by subduction either on a north-dipping (Tankard et al. 2009) or south-dipping (Lindeque et al. 2011) plane, leading to the obduction of oceanic crust and the generation of the Gondwana suture during the Namaqua-Natal Orogeny (Hälbich 1993; Thomas et al. 1993). Reworking of this suture zone material resulted in the deposition of the Pre-Cape Group in basins that opened parallel to this suture from 900 to 600 Ma (Tankard et al. 1982; Hälbich 1993; Paton \& Underhill 2004). Between 600 and $450 \mathrm{Ma}$, the Pan African Orogeny led to basin inversion, north-verging thrusts and a south dipping mega-décollement (Tankard et al. 1982; Shone et al. 1990; Hälbich 1993). During the Ordovician to Carboniferous (450-300 Ma) the Cape Supergroup was deposited, followed by the Cape Orogeny (280-235 Ma) (Tankard et al. 1982; Hälbich 1993; Paton \& Underhill 2004); the latter was accompanied by the deposition of the Karoo foreland sequence (Hälbich 1993; Veevers et al. 1994). This later collisional episode led to the formation of the Gondwanide orogen which extended through the Sierra de la Ventana (South Argentina), Cape Mountains (South Africa), Falkland Islands, Ellsworth Mountains and Pensacola Mountains (Antarctica) (Du Toit 1937; Thomas et al. 1993; Trouw \& De Wit 1999; Dalziel et al. 2000).

Evidence of an up-dip continuation of the mega-décollement interpreted by Hälbich (1993) is presented by Lindeque et al. (2011). Their study documents a south dipping interface beneath the Karoo Basin, lying between $\sim 5$ and $11 \mathrm{~km}$ depth and separating the deformed Karoo and Cape supergroup sequences from the Mesoproterozoic basement (Lindeque et al. 2011). This interface has been interpreted as an angular unconformity by Lindeque et al. (2011) but the fact that thrusts coalesce onto it suggests that it acted as a decoupling plane and its depth correlates with the depth of the mega-décollement interpreted by Hälbich (1993); this décollement is believed to have had been partially reactivated during the Cape Orogeny (Hälbich 1993).

During the Middle Jurassic to Early Cretaceous break-up of Gondwana many Cape Fold Belt structures were reactivated in an extensional regime (Paton \& Underhill 2004; Paton 2006). During this time, there were high rates of exhumation across southern South Africa (Richardson et al. 2017), with sediment supplied to offshore extensional basins such as the Outeniqua and Southern Outeniqua Basins (Fig. 2) (Tinker et al. 2008). At the same time, offshore the Falkland Islands, the North Falkland Basin, the Falkland Plateau Basin, the South Falkland Basin and the Malvinas Basin developed (Figs 1\&3) (Richards et al. 1996; Macdonald et al. 2003). The extension was the result of the westward drift of South America along the dextral Agulhas-Falkland Fracture Zone (AFFZ), away from Africa, and the opening of the South Atlantic (Ben-Avraham et al. 1997; Macdonald et al. 2003).

\section{Outeniqua Basin}

Rifting in the broader Outeniqua Basin is thought to have occurred between Middle Jurassic and Valanginian with sedimentation into four depocentres: Bredasdorp, Pletmos, Gamtoos and Algoa (McMillan et al. 1997). These are bounded by west-dipping normal faults (from west to east respectively: Plettenberg Fault, Gamtoos Fault, Port Elizabeth Fault and St. Croix Fault) with displacements in excess of $10 \mathrm{~km}$ or by basement highs (Agulhas and Infanta Arches) (McMillan 
et al. 1997) (Fig. 2). The dip angles of the controlling faults consistently increase towards the south-west from $24^{\circ}$ across the St. Croix Fault to $60^{\circ}$ across the Plettenburg Fault (Paton et al. 2006) and coalesce onto a south-dipping mega-décollement (Hälbich 1993; Paton et al. 2006). This configuration results in a southward change in structural style from thin-skinned to thickskinned (Paton et al. 2006). These depocentres are bounded to the south by the Southern Outeniqua Basin which is in turn separated from the AFFZ by the Diaz Marginal Ridge (DMR) (Parsiegla et al. 2009) (Fig. 2).

118 The basin-fill of each of these depocentres consists of Middle Jurassic to Early Cretaceous terrestrial and shallow marine sediments that unconformably overlie the Ordovician-Devonian Cape Supergroup onshore and offshore in the early rift stages, and transit to deep-water deposits offshore in the late rift stages (McMillan et al. 1997; Paton \& Underhill 2004; Paton 2006). The post-rift sequence is represented by shallow marine deposits (McMillan et al. 1997).

\section{North Falkland Basin}

The structure of the North Falkland Basin (NFB) is controlled by the superimposition of two rift systems: the Late Jurassic Southern North Falkland Basin (SNFB), which is overlain by the Early Cretaceous North Falkland Graben (Lohr \& Underhill 2015) (Figs 1\&3). The SNFB is bounded by NW-SE striking normal faults which are overprinted to the north by the N-S striking normal faults of the younger North Falkland Graben and its secondary half-grabens (Richards \& Fannin 1997; Thomson \& Underhill 1999; Lohr \& Underhill 2015). The Jurassic normal faults have low dip angles, thought to suggest that they originated as thrust faults (Richards et al. 1996; Richards \& Fannin 1997; Thomson \& Underhill 1999). Their strike is similar to the onshore structures associated with the Gondwanide orogeny (Richards \& Fannin 1997; Brandsen et al. 1999).

133 The onset of post-rift sedimentation in the SNFB is interpreted as coeval with the deposition of 134 syn-rift in the North Falkland Graben and its subsidiary basins (Lohr \& Underhill 2015). The infill of the basins is considered to comprise Jurassic to Valanginian fluvio-lacustrine deposits transitioning to lacustrine and deltaic during the post-rift of the North Falkland Graben and overlain by fluvial to marine mudstones of Late Cretaceous to Cenozoic age (Richards \& Hillier 2000; Richards et al. 2006; Lohr \& Underhill 2015).

\section{Falkland Islands within Gondwana}

140 Du Toit (1927) first suggested that the Falkland Islands might represent a displaced segment of the Cape Fold Belt (CFB) and placed the islands between South America and South Africa. Adie (1952a) built upon that hypothesis and suggested that the islands rotated $\sim 180^{\circ}$ having originated from offshore east South Africa (Fig. 4a). This assertion was based on stratigraphic correlations, fossil assemblages, ice flow directions and structural similarities between the Falkland Islands and the South African margin. This hypothesis is further supported by more recent palaeomagnetic, aeromagnetic, stratigraphic, palaeontological and structural data analysis (Mitchell et al. 1986; Mussett \& Taylor 1994; Marshall 1994; Curtis \& Hyam 1998; Trewin et al. 2002; Stone et al. 2009). The palaeomagnetic measurements were carried out on dykes identified onshore the Falkland Islands (Mitchell et al. 1986; Taylor \& Shaw 1989; Stone et al. 2008) and on Permian sediments (Thistlewood \& Randall 1998 in Stone 2016). The dykes trend E-W to NE-SW and N-S and are of Early Jurassic to Early Cretaceous age, respectively (Mussett \& Taylor, 1994; Thistlewood et al. 1997; Stone et al. 2008; Richards et al. 2013). Their emplacement is related to the Karoo-Ferrar magmatism in South Africa and Antarctica for the Jurassic dykes (Mitchell et al. 
deformation phases (D1 to D5) were identified by Aldiss \& Edwards (1999) onshore the Falkland Islands; the first four were interpreted as being synchronous to the Permo-Triassic CFB in South Africa (Curtis \& Hyam 1998; Stone 2016). The West Falkland Group, which crops out on the West Falkland, the northern part of the East Falkland and the Beauchêne Island (Aldiss \& Edwards 1999; Stone 2015), has been correlated with the Table Mountain, Bokkeveld and Witteberg groups in South Africa (Adie 1952b in Marshall 1994), whereas the Fitzroy Tillite Formation from the Falkland Islands is considered coeval with the Dwyka Group (Fig. 5) from South Africa (Curtis \& Hyam 1998) based on ice flow directions (Frakes \& Crowell 1967; Crowell \& Frakes 1972) and fossil assemblages from erratic clasts from the glacial diamictites (Stone \& Thompson 2005; Stone et al. 2012). The overlying Permian deposits of the Upper Lafonian Group have been correlated with the Ecca and Beaufort groups in South Africa based on stratigraphy, trace fossils and sediment provenance (Trewin et al. 2002) (Fig. 5).

These correlations led to the positioning of the Falkland Islands east of the south-eastern coast of South Africa (Curtis \& Hyam 1998; Trewin et al. 2002) (Fig. 4a) with the Maurice Ewing Bank, now located at the eastern end of the Falkland Plateau (Fig. 1), adjacent to the Durban Basin (Marshall 1994). In this model, the Falkland Islands underwent a clockwise rotation of up to $180^{\circ}$ during the break-up of Gondwana $\left(120^{\circ}\right.$ prior to the opening of the South Atlantic and $60^{\circ}$ during the drifting of the South American plate) (Mitchell et al. 1986).

As part of the rotational model, the Falkland Islands are considered to be part of a microplate that underwent vertical-axis rotation during the break-up of Gondwana. However, the northern and western boundaries of this microplate remain uncertain, while the southern and eastern boundaries are considered to coincide with the present-day North Scotia Ridge and the NE-SW striking fault bounding the Falkland Plateau Basin, respectively (Marshall 1994; Richards et al. 1996; Storey et al. 1999) (Fig. 1).

A further implication of this reconstruction of the islands consists of space issues, which require the presence of a right-lateral fault north of the North Patagonian Massif (Ben-Avraham et al. 1993) or south of it, along the Gastre Fault System (Rapela \& Pankhurst 1992) (Figs 1\&4a) to account for a more eastern position of Patagonia prior to the break-up of Gondwana. However, field observations along the Gastre Fault contradict its predicted dextral nature (Franzese \& Martino 1998 in Ramos et al. 2017; Von Gosen \& Loske 2004) and provide an additional argument against the rotational model.

Furthermore, no deformation affecting the sedimentary basins offshore the Falkland Islands has been identified in previous studies (Richards et al. 1996) which led to the conclusion that the rotation occurred prior to the opening of these basins in the mid-Jurassic (Stone et al. 2008). However, there is little movement recorded along the AFFZ at this time (Broad et al. 2006 in Tankard et al. 2009) in support of this hypothesis. In addition, the uncertainty around palaeomagnetic measurements (Richards et al. 1996; Hodgkinson 2002 in Stone 2016) and the absence of a pertinent mechanism to account for the rapid and substantial rotation of the islands resulted in numerous studies advocating for a contrasting rigid evolution of the Falkland Islands, in which the islands are part of a Falkland Plateau fixed to the South American plate (Fig. 4b). In this scenario the Falkland Islands undergo a rotation of only $60^{\circ}$ during the opening of the South Atlantic (Lawrence et al. 1999; Ramos et al. 2017).

In the rigid model the opposite vergence of the thrusts and folds onshore the Falkland Islands compared to the Cape Fold Belt is explained through the existence of similar south-verging 
structures in the north-eastern North Patagonian Massif (Von Gosen 2003; Ramos et al. 2017). The West Falkland Group is interpreted as being coeval with same age deposits from northern Patagonia, their common source being the Deseado Massif whereas the equivalent of the diamictite in the Falkland Islands is interpreted as being the Sauce Grande Tillite of the Ventania System, Argentina (Ramos et al. 2017). Furthermore, the trend of the Jurassic Southern North Falkland Basin is correlated to basins along the South American margin (Fig. 1), having the same trend and age (Ramos et al. 2017), their opening being associated either with back-arc extension along the southern margin of Gondwana or the southward movement of Antarctica and early extension in the Weddell Sea (Uliana et al. 1989; Baristeas et al. 2013; Reeves et al. 2016; Ramos et al. 2017).

\section{DATA AND METHODS}

The study was based on the analysis of open-source gravity data (Fig. 6) and seismic reflection and well data (Fig. 3) courtesy of the Falkland Islands Government.

The gravity data consist of the V24.1 1-minute satellite altimetry free-air gravity anomaly grid of Sandwell et al. (2014). The seismic reflection data used for this study comprise 2D lines from seven different vintages acquired between 1980s and 2008 by BIRPS, WesternGeco, Spectrum, Rockhopper Exploration and Desire Petroleum. The shot point interval ranges from $25 \mathrm{~m}$ for the more recent datasets to $50 \mathrm{~m}$ for the regional traverse east of the islands whereas the fold of cover varies between 120 and 30 respectively. The line spacing ranges from 2 to $30 \mathrm{~km}$ and the maximum record lengths between 6.7 to 18 seconds. All seismic sections have a vertical axis in two-way-time (TWT), a depth conversion being undertaken on type-sections post-interpretation. Two wells, 26/6-1 (Rockhopper Exploration) and 14/24-1 (IPC Falklands), were used for this study with formation top markers and were tied to the seismic reflection data. VSP surveys were available for each well and provided velocity information that facilitated the subsequent depth conversion.

The total horizontal derivative of the free air gravity anomaly (Cordell \& Grauch 1985), first vertical derivative (Evjen 1936) and tilt derivative (Miller \& Singh 1994; Verduzco et al. 2004; Oruç \& Keskinsezer 2008) were computed (Fig. 6) for edge detection and in order to enhance linear structures. The main gravity lineaments were mapped along the entire NFB (Fig. 6) and show a close correlation with fault trends mapped on the seismic reflection data (Fig. 7).

Four key surfaces were mapped across the SNFB based on stratal terminations of reflectors and internal geometries of seismic facies (Mitchum et al. 1977; Hubbard et al. 1985a, b) and used to define four mega-sequences: pre-rift, syn-rift, post-rift 1 and post-rift 2 . The latter two are separated by the base Cenozoic regional unconformity. Within the syn-rift two unconformities, described in detail by Lohr \& Underhill (2015), were mapped along the extent of the half-grabens basin-fills. The SNFB pre-rift is associated with a semi-transparent seismic facies capped by a high amplitude reflector that is onlapped by wedge-shaped syn-rift deposits. These display a chaotic seismic character in the lower section and sub-parallel to parallel reflectors in the upper part. The post-rift 1 comprises wavy to hummocky deposits overlain by the sub-horizontal post-rift 2 (Fig. 8).

The oldest sediments penetrated by both wells are represented by Upper (?) Jurassic volcaniclastic deposits. Across the faults, the corresponding reflector is correlated with the top syn-rift of the SNFB. This horizon is not continuous southward across the half-grabens shoulders. 
The age of the infill of the southernmost half-graben is inferred based on stratal geometries alone assuming coeval deposition across the SNFB.

244 Faults at the SNFB pre-rift level were mapped (Figs 7-9) and superimposed onto the interpreted gravity features shown in Fig. 6 for comparison and correlation. Two deep high amplitude intervals were identified, the shallower ( $-3.5 \mathrm{~s}$ to $-8.2 \mathrm{~s}$ TWT) being mapped across the entire SNFB (Figs 7\&10a, b, c) on two of the vintages whilst the deeper feature (-11 s to $-12 \mathrm{~s}$ TWT) was interpreted only on the regional traverse east of the islands (Fig. 10c, d).

A regional cross-section was constructed perpendicular to the main structural grain of the basin to allow a direct comparison with published sections from onshore Falkland Islands and South Africa. In order to assess the geometry of the faults more reliably, the section was depth converted using velocity information from the borehole seismic surveys available for both wells. Post-rift 1 and 2 were depth converted using interval velocities of 1900 and $2600 \mathrm{~m} / \mathrm{s}$ respectively. A $\mathrm{v}_{0}-\mathrm{k}$ function was used for the syn-rift deposits $\left(\mathrm{v}_{0}=3000 \mathrm{~m} / \mathrm{s}\right.$ and $\left.\mathrm{k}=0.6\right)$ whereas the pre-rift down to a depth of 8s TWT was depth converted using a constant velocity of $5200 \mathrm{~m} / \mathrm{s}$. The same velocity model was used to depth convert type-section across the major NW-SE faults in order to estimate the thickness of the half-graben infills and the dips of the faults more accurately.

\section{RESULTS}

259

260

261

262

263

The deformation in the SNFB was accommodated by three main NW-SE striking reactivated thrust faults (A to C in Fig. 7), up to $150 \mathrm{~km}$ long, and with depocentres $\sim 3000 \mathrm{~ms}$ TWT ( $\sim 5 \mathrm{~km}$ ) deep. The NW-SE trend of these faults can be tracked on the gravity data derivatives where they are associated with linear anomalies (Fig. 6). Further north, this NW-SE trend of the gravity lineaments is overprinted by WNW-ESE to E-W striking features swinging through NE-SW to N-S on the west of the islands and the N-S trend of the Early Cretaceous main graben (Fig. 6).

The NW-SE trending normal faults have low depth converted dips of 20-40 (with the exception of Fault A that steepens up to $60^{\circ}$ closer to the surface), dominantly down throw to the NE, and are associated with splay faults and smaller-scale synthetic and antithetic faults within their hanging-walls (Figs 7\&8).

The syn-rift deposits associated with these faults reach a thickness of $\sim 2000$ ms TWT but a greater thickness was likely to have existed as the southernmost half-graben infills have since been uplifted and eroded. The syn-rift was deposited in three stages, separated by unconformities interpreted within the package (Fig. 8) and most likely overlies the same formations that crop out onshore (Thomson \& Underhill 1999; Lohr \& Underhill 2015). The syn-rift was further inverted and deformed into harpoon structures and gentle folds along with the overlying Cretaceous postrift (Fig. 8). The whole sequence is capped unconformably by Cenozoic deposits.

The WNW-ESE to E-W trending features mapped on the gravity data (Fig. 6) correlate with depressions and fractured zones within the seismic reflection data (Fig. 9). A high amplitude reflector correlated with the top SNFB pre-rift (Fig. 9) can be mapped across these structures; the geometry of the strata overlying it shows a slight thickening south-westwards whereas further up the succession strata thicken north-eastwards (grey-shaded packages in Fig. 9a). The infill of these structural lows is unconformably overlain by Cenozoic deposits (Fig. 9).

Across the SNFB a high amplitude north dipping set of reflectors was interpreted between $-3.5 \mathrm{~s}$ and $-8.2 \mathrm{~s}$ TWT ( -8 to $-20 \mathrm{~km}$ ) (Fig. 10a, b, c). The 'surface' can be mapped out to $\sim 100 \mathrm{~km}$ from the coastline where the imaging becomes poorer and/or its depth exceeds the maximum 
recorded length of the data. Towards the south, the interface is visible nearshore Stanley where it shallows both southwards and south-eastwards, disappearing around $51^{\circ} 42^{\prime} \mathrm{S}$ (Fig. 7). This feature has been characterised as an interval of high amplitudes as it appears as a discrete interface only updip (Fig. 10a). Further downdip, the area widens and becomes more convoluted, being characterised by an irregular top and the presence of lenticular features most likely generated through thrusting (Fig. 10b). East and northeast of the islands another set of reflectors was picked between -11 s and -12 s TWT (Fig. 10c, d); the two sets of reflectors seem to converge northeast of the Falkland Islands (Fig. 10d, f).

DISCUSSION

\section{SNFB fault geometry and formation}

The NW-SE normal faults mapped in the SNFB have low dip angles, are downthrown predominantly to the NE and have a similar orientation to the D4 thrust faults described onshore the Falkland Islands by Aldiss \& Edwards (1999). This suggests that they exploited pre-existing thrust planes (Richards et al. 1996) developed during the Gondwanide orogeny much like the faults on the southern margin of South Africa (Paton et al. 2006; Paton 2006). However, unlike its conjugate (Paton et al. 2006), the faults in the SNFB do not show a consistent steepening away from the deformation front, their mean depth converted dips being in the $20^{\circ}-40^{\circ}$ range (Fig. 11a). The south-westward steepening of the faults in the Outeniqua Basin has been recorded across a wide area of over $200 \mathrm{~km}$, which is in direct contrast with the narrow extent of the analysed SNFB $(\sim 60 \mathrm{~km})$. We speculate that this limited extent does not cover the deep rooted, higher angle faults and predict that these may underlie the northernmost part of the NFB. The present-day preserved SNFB is therefore characteristic only of a narrow deformational domain. Its equivalent on the conjugate South African margin based on the range of dips could correspond to the transitional area between the thin-skinned and thick-skinned domains described by Paton et al. (2006), namely the area between the St. Croix Fault and the Gamtoos 310 Fault (Fig. 11).

311 There are, however, basins along the South American margin (e.g. Cañadón Asfalto, San Jorge, El Tranquilo, San Julián, Río Mayo basins) that underwent rifting along the same NW-SE trend as the SNFB or have similar infills, suggesting a synchronous opening within the same stress field (Uliana et al. 1989; Brandsen et al. 1999; Ramos et al. 2017). The normal faults bounding the grabens and half grabens in these basins situated along strike from the SNFB are nonetheless steeply dipping (Fitzgerald et al. 1990; Soares et al. 2000; Echavarría et al. 2005) and point towards a different evolution prior to the Jurassic rifting.

318 The similarities in trend between the SNFB and the South American basins have been previously invoked as an argument for the rigid model (Ramos et al. 2017), but this does not explain the origin of the crustal anisotropy beneath the Falkland Islands and its northern basin. The southverging deformation documented by Von Gosen (2003) in the North Patagonian Massif was correlated with the accretion of Patagonia during Late Paleozoic (Ramos 2008) and used to explain the present-day vergence of the Falkland Islands deformation front (Ramos et al. 2017). Evidence of south-verging thrusts can be seen up to $150 \mathrm{~km}$ away from the western coast of the Falkland Islands (Fig. 10a; McCarthy et al. 2017), but there is however no documentation of a south-verging fold and thrust belt further west to support a correlation with Patagonia. The opening of the SNFB due to the same stress regime as the one in the South American NW-SE trending basins is still a pertinent interpretation but does not preclude a rotation of the islands prior to this rifting event. 
The WNW-ESE to E-W gravity lineaments mapped across the NFB (Fig. 6) are associated with fractured zones interpreted as extensional or transtensional features (Fig. 9). The timing of activity on these faults is difficult to constrain because some of these features are not covered by the available seismic data, their infill was partly eroded and well data cannot be extrapolated across the fault shoulders. The geometry of the strata overlying the interpreted top SNFB pre-rift show a slight thickness variation (grey-shaded packages in Fig. 9) suggesting a diachronous activity of the faults bounding the structures. However, due to the lack of well data on the platform and scarcity of seismic reflection data the timing of activity on these faults along with the sense of movement (dip-slip, strike-slip) remains speculative.

339 The E-W trend of these lineaments changes to a more ENE - WSW orientation westwards (Fig. 6). As this area is not constrained by seismic reflection data, the nature of these gravity lineaments remains unknown. We speculate their formation is either simultaneous with the event that generated the E-W trending features or with the Triassic - Late Jurassic opening of the San Julian Basin (Soares et al. 2000) where a NE - SW gravity trend is noticeable parallel to the eastern margin of the basin.

\section{Mega-décollement}

We interpret the north dipping high amplitude interval mapped between -3.5 s and -8.2 s TWT (8 to $-20 \mathrm{~km}$ after depth conversion) as a mega-décollement onto which the major faults bounding the three half-grabens of the SNFB coalesce (Figs 10e-11a). Further south the interface can be mapped until $51^{\circ} 42^{\prime} \mathrm{S}$. Based on previous crustal studies carried out by Kimbell \& Richards (2008) and Schimschal \& Jokat (2017) on the Falkland Plateau, the Moho discontinuity is located at $34-36 \mathrm{~km}$ depth on the continental shelf east of the islands and shallows northwards to $30 \mathrm{~km}$ based on gravity modelling. Using the P-wave velocities published by Schimschal \& Jokat (2017) for the continental shelf crust, the reflectors we interpreted between 11 - $12 \mathrm{~s}$ TWT off the east coast of the Falkland Islands would be situated at a converted depth of $33-36 \mathrm{~km}$; this led us to correlate them with the Moho discontinuity (Fig. 10f). Taking into account the present-day depth distribution of the Moho north of the Falkland Islands as shown by Kimbell \& Richards (2008) and the dip of the mega-décollement, it can be deduced that the latter emerges from the Moho between $48^{\circ} \mathrm{S}$ and $50^{\circ} \mathrm{S}$ (present-day coordinates) (double 360 line in Fig. 12). The presence of a similar regional décollement dipping south has been inferred by Hälbich (1993) to be controlling the deformation in South Africa. Based on a deep seismic reflection profile along the Agulhas Bank (Dürrheim 1987, (1) in Fig. 12), the depth of this décollement would be -6.5 s or -18 km underneath the Outeniqua Basin (Hälbich 1993) which is in the depth range estimated for the décollement under the SNFB. The interpretation of a more recent seismic reflection transect ((2) in Fig. 12) acquired between Prince Albert and Slingersfontein (South Africa) shows the presence of a crustal interface that dips $3^{\circ}$ southwards and separates the shallower thrusted 368 sequence of the CFB and Karoo Basin from the Mesoproterozoic basement (Lindeque et al. 2011). Extrapolating this plane southwards, we estimate its depth underneath the Agulhas Plateau at $\sim 20 \mathrm{~km}$ and correlate it with the mega-décollement of Hälbich (1993). This depth variation of the mega-décollement is also proposed by Paton et al. (2006). The detachment is located underneath the Cape Supergroup in the southern part of the Karoo Basin (Lindeque et al. 2011) and is thought to displace Proterozoic deposits further south (Paton et al. 2006) (Fig. 11b).

The Moho for the South African margin shallows southwards from $50 \mathrm{~km}$ underneath the Karoo Basin to $\sim 30 \mathrm{~km}$ near the coast and 25-26 km beneath the Agulhas Bank (Nguuri et al. 2001; 
Stankiewicz et al. 2008; Stankiewicz \& de Wit 2013). Taking into account the dip of the décollement $\left(\sim 3^{\circ}\right.$ based on Lindeque et al. 2011) and the present-day depth of the Moho offshore South Africa, we can estimate a merging of the decoupling plane with the Moho occurring at $\sim 35^{\circ} \mathrm{S}$ (dashed grey double line in Fig. 12) which is in accordance with the interpretation of Hälbich 380 (1993).

\section{South African connections}

382 Cross-sections across both the southern South African onshore to offshore margin and the 383 Falkland Islands and their northern basin exhibit similar deformation styles (Fig. 11). Given the uncertainty in the relative positions during the initial phases of rifting during the break-up of Gondwana, the terms foreland and hinterland will be used to refer to different parts of the crosssections. The foreland portion in both areas comprises Carboniferous to Permian deposits of the Karoo and Lafonia supergroups exposed onshore South Africa and Eastern Falkland, respectively (Fig. 11). These are affected by open to isoclinal folds with symmetric to highly asymmetric limbs controlled at depth by thrusting (Aldiss \& Edwards 1999; Stone 2016; Paton et al. 2006). Towards the hinterland, thrusts active during the Cape orogeny underwent negative structural inversion during the Mesozoic rifting event. Closer to the CFB deformation front, the extension resulted in low angle $\left(20^{\circ}-40^{\circ}\right)$ listric normal faults that bound half grabens filled with Late Jurassic terrestrial to shallow marine deposits across the SNFB and the South African Algoa and Gamtoos Basins (Fig. 11). Away from the deformation front, the normal faults accommodating the extension steepen (Fig. 11b) and it has been proposed that these originated as normal faults during the Cape Supergroup deposition and were further exploited during the subsequent compressional and extensional regimes (Paton et al. 2006; Paton 2006). These steeply dipping faults were not identified offshore the Falkland Islands. The E-W trending features we have mapped north of the SNFB and the subsequent opening of the North Falkland Graben are most likely overprinting their effect.

402 On both margins, at depth, the deformation is controlled by the presence of a mega-décollement onto which the thrusts and normal faults coalesce (Fig. 11).

\section{Palaeogeographic implications}

405 Existing palaeogeographic reconstructions of the Falkland Islands have associated drawbacks 406 from the absence of a mechanism that explains the substantial rotation of the islands in the rotational model to the lack of continuation of a south verging fold and thrust belt east and west of the islands in the rigid model.

409 Given the new observations in this study, we propose that the geometry of the normal faults 410 bounding the SNFB half grabens could correspond to the deformation domain between the St. Croix and Gamtoos Faults suggesting that the reactivated Paleozoic thrusts north of the Falkland Islands were an along strike continuation of the present-day Algoa Basin region. This translates in a change in trend of the Cape Fold Belt from WNW-ESE to NNW-SSE eastwards. This abrupt change in orientation is supported by the strike change of the St. Croix, Port Elizabeth and Gamtoos Faults (Fig. 12) which has been referred to as the Port Elizabeth Antitaxis (Johnston 2000). This strike variation has been related to the pre-existing crustal fabric developed during the Cape Orogeny rather than later movements along the AFFZ (Paton \& Underhill 2004). Similar oroclinal bends of the Ventana-CFB are seen in western South Africa and Argentina at the Cape and Colorado syntaxes, respectively (De Beer 1992; Pángaro \& Ramos 2012; Paton et al. 2016). 

al. 1986)). This repositioning of the Falkland Islands microplate would mean that the points at which the mega-décollement branches off from the Moho are distributed along a trend similar to the trend of the CFB across the restored AFFZ (Fig. 12) and has implications for the extension expected in the Falkland Plateau Basin. The available data do not allow for longitudinal constraints in repositioning the microplate, the extent of the Falkland Plateau Basin fitted between the Eastern Falkland and the AFFZ remaining uncertain. However, the revised position predicts more unstretched crust between the microplate and the Maurice Ewing Bank block, which is thought to have originated south of the Tugela Cone (Marshall 1994). Therefore, less extension is required in order to achieve the present-day relative position of the two continental blocks.

433 Regarding the timing of rotation of the Falkland Islands microplate, two scenarios are available based on the stress regime that led to the opening of the SNFB. Jurassic extensional episode inferred for the Gamtoos Basin (Paton \& Underhill 2004), the SNFB/Falkland Islands microplate should have been in a pre-rotation position in the Late Jurassic. Between the two rifting events that led to the formation of the SNFB and the North Falkland Graben, the microplate underwent a rapid clockwise rotation possibly exploiting the EW to ENE-WSW lineaments described previously. Based on the detailed study carried out by Lohr \& Underhill (2015) in the North Falkland Basin, the time interval between the two extensional episodes is of $\sim 10 \mathrm{Myr}$, although a longer time-frame is possible due to the extensive Tithonian hiatus marking the end of the SNFB formation. A rotation rate of maximum $12^{\circ} \mathrm{Myr}^{-1}$ is estimated for this scenario for a rotation of $120^{\circ}$ consistent with the existing rotation model. For the same time interval, the revised model yields a rotation rate of $8^{\circ} \mathrm{Myr}^{-1}$. The latter is closer to the range of rates documented for strike-slip-related vertical-axis block rotations (Little \& Roberts 1997; Ingersoll \& Coffey 2017).

448 If we speculate that the SNFB opened simultaneously with the NW-SE oriented basins along the 449 South American margin (Uliana et al. 1989; Baristeas et al. 2013; Ramos et al. 2017), the Falkland Islands microplate should have already been in the rotated position in Late Jurassic when rifting started in the SNFB. Based on the Ar-Ar dating carried out on one of the NE-SW dykes onshore the Falkland Islands, the microplate is thought to have rotated after $178 \mathrm{Ma}$ (Stone et al. 2008). This would limit the time interval for the rotation to Middle Jurassic which is in accordance with the time frame suggested by Stone et al. (2008), giving rotation rates of $\sim 8.2^{\circ} \mathrm{Myr}^{-1}$ and $5.5^{\circ} \mathrm{Myr}^{-}$ 1 for the $120^{\circ}$ and $80^{\circ}$ scenarios, respectively.

\section{CONCLUSIONS}

The North Falkland Basin was affected by two rifting episodes during the break-up of Gondwana, the older of which led to the formation of the Southern North Falkland Basin. Our study reveals that the Paleozoic thrusts exploited during the opening of this basin emerge from a north-dipping mega-décollement, much like the faults in the Outeniqua Basin, offshore South Africa, which coalesce on a south-dipping mega-décollement. Based on the range of fault dips in the SNFB and the inferred latitude at which the mega-décollement merges with the Moho, we propose a repositioning of the Falkland Islands microplate so that the SNFB sat along strike from the Algoa Basin prior to the break-up of Gondwana. The implications of the revised position of the islands are threefold: 
(a) the position is in agreement with the presence of an antitaxis of the CFB at Port Elizabeth;

(b) the amount of extension expected to have affected the Falkland Plateau Basin is reduced compared to previous rotational models;

(c) the amount of rotation and the estimated rotation rate of the Falkland Islands microcontinental block are reduced, the latter being now comparable to block rotation rates in strike-slip systems.

The orientation of the extensional regime that led to the opening of the SNFB can be either WSWENE and related to the separation between South America and Africa or NW-SE rifting related to the southward movement of Antarctica or back-arc extension. Based on these two scenarios, the timing of rotation is restricted to Tithonian-Berriasian or Middle-Jurassic, respectively.

\section{ACKNOWLEDGEMENTS}

We thank Phil Stone (British Geological Survey) for the constructive in-house review and Paul Markwick (University of Leeds) for the insightful comments and helpful discussions. Tina Lohr and Julio Almeida are thanked for the thorough and thoughtful reviews. This paper is published by permission of the Director of Mineral Resources, Falkland Islands Government and the Executive Director, British Geological Survey (BGS).

\section{FUNDING}

This work is part of a Leeds/York NERC Doctoral Training Programme and BGS funded project.

\section{REFERENCES}

Adie, R. J. 1952a. The Position of the Falkland Islands in a Reconstruction of Gondwanaland. Geological Magazine, 89(6), 401-410. https://doi.org/10.1017/S0016756800068102

Adie, R. J. 1952b. Representatives of the Gondwana system in the Falkland Islands. In: Teichert, C. (ed.) Symposium sur le Seriés de Gondwana. 19th Intl. Geol. Congr., Algiers, 385-392.

Aldiss, D. T. \& Edwards, E. J. 1999. The geology of the Falkland Islands. British Geological Survey Technical Report WC/99/10. Retrieved from http://nora.nerc.ac.uk/507542/

Baristeas, N., Anka, Z., di Primio, R., Rodriguez, J. F., Marchal, D. \& Dominguez, F. 2013. New insights into the tectono-stratigraphic evolution of the Malvinas Basin, offshore of the southernmost Argentinean continental margin. Tectonophysics, 604, 280-295. https://doi.org/10.1016/j.tecto.2013.06.009

Basile, C. \& Allemand, P. 2002. Erosion and flexural uplift along transform faults. Geophysical Journal International, 151(2), 646-653. https://doi.org/10.1046/j.1365-246X.2002.01805.x

Ben-Avraham, Z., Hartnady, C. J. H. \& Malan, J. A. 1993. Early tectonic extension between the Agulhas Bank and the Falkland Plateau due to the rotation of the Lafonia microplate. Earth and Planetary Science Letters, 117(1-2), 43-58. https://doi.org/10.1016/0012-821X(93)90116-Q

Ben-Avraham, Z., Hartnady, C. J. H. \& Kitchin, K. A. 1997. Structure and tectonics of the AgulhasFalkland fracture zone. Tectonophysics, 282, 83-98.

Bransden, P. J. E., Burges, P., Durham, M. J. \& Hall, J. G. 1999. Evidence for multi-phase rifting in the North Falklands Basin. Geological Society, London, Special Publications, 153(1), 425-443. https://doi.org/10.1144/gsl.sp.1999.153.01.26 
Broad, D.S., Jungslager, E.H.A., McLachlan, I.R. \& Roux, J. 2006. Offshore Mesozoic basins. In: Johnson, M.R., Anhaeusser, C.R., Thomas, R.J. (eds.) The Geology of South Africa. Geological Society of South Africa and Council for Geoscience, Johannesburg, 553-571.

Cordell, L. \& Grauch, V.J.S. 1985. Mapping Basement Magnetization Zones from Aeromagnetic Data in the San Juan Basin, New Mexico. In: Hinze, W.J. (ed.) The Utility of Regional Gravity and Magnetic Anomaly Maps. Society of Exploration Geophysicists, Tulsa, 181-197.

Crowell, J. C. \& Frakes, L. A. 1972. Late Paleozoic Glaciation: Part V, Karoo Basin, South Africa. Geological Society of America Bulletin, 83, 2887-2912.

Cunningham, A. P., Barker, P. F. \& Tomlinson, J. S. 1998. Tectonics and sedimentary environment of the North Scotia Ridge region revealed by side-scan sonar. Journal of the Geological Society, London, 155, 941-956.

Curtis, M. L. \& Hyam, D. M. 1998. Late Palaeozoic to Mesozoic structural evolution of the Falkland Islands: a displaced segment of the Cape Fold Belt. Journal of the Geological Society, 155(1), 115129. https://doi.org/10.1144/gsjgs.155.1.0115

Dalziel, I. W. D., Lawver, L. A. \& Murphy, J. B. 2000. Plumes, orogenesis, and supercontinental fragmentation. Earth and Planetary Science Letters, 178(1-2), 1-11. https://doi.org/10.1016/S0012-821X(00)00061-3

De Beer, C.H., 1992. Structural evolution of the Cape Fold Belt syntaxis and its influence on syntectonic sedimentation in the SW Daroo Basin. In: de Wit, M.J. \& Ransome, I.G.D. (eds.) Inversion Tectonics of the Cape Fold Belt, Karoo and Cretaceous Basins of Southern Africa. Balkema Publishers, Rotterdam, 197-206.

Del Ben, A. \& Mallardi, A. 2004. Interpretation and choronostratigraphic mapping of multichannel seismic reflection profile 195167, Eastern Falkland Plateau (South Atlantic). Marine Geology, 209, 347-361.

Du Toit, A.L. 1927. A Geological Comparison of South America and South Africa. Carnegie Institution of Washington, Washington.

Du Toit, A.L. 1937. Our Wandering Continents. Oliver and Boyd, London.

Durrheim, R. J. 1987. Seismic reflection and refraction studies of the deep structure of the Agulhas Bank. Geophysical Journal of the Royal Astronomical Society, 89(1), 395-398. https://doi.org/10.1111/j.1365-246X.1987.tb04437.x

Echavarría, L. E., Schalamuk, I. B. \& Etcheverry, R. O. 2005. Geologic and tectonic setting of Deseado Massif epithermal deposits, Argentina, based on El Dorado-Monserrat. Journal of South American Earth Sciences, 19(4), 415-432. https://doi.org/10.1016/j.jsames.2005.06.005

Evjen, H. M. 1936. The place of the vertical gradient in gravitational interpretations. Geophysics, 1(1), 127-136.

Ewing, J. I., Ludwig, W. J., Ewing, M. \& Eittreim, S. L. 1971. Structure of the Scotia Sea and Falkland Plateau. Journal of Geophysical Research, 76(29), 7118-7137.

Figari, E. G., Scasso, R. A., Cúneo, R. N. \& Escapa, I. 2015. Estratigrafía y evolución geológica de la Cuenca de Cañadón Asfalto, Provincia del Chubut, Argentina. Latin American Journal of Sedimentology and Basin Analysis, 22(2), 135-169. 
545 Fitzgerald, M. G., Mitchum, R. M., Uliana, M. A. \& Biddle, K. T. 1990. Evolution of the San Jorge

546 Basin, Argentina. American Association of Petroleum Geologists Bulletin, 74(6), 879-920.

547 Frakes, L. A. \& Crowell, J. C. 1967. Facies and Paleogeography of Late Paleozoic Diamictite, 548 Falkland Islands. Geological Society of America Bulletin, 78, 37-58.

549 Franzese, J., Martino, R. 1998. Aspectos cinemáticos y tectónicos de la zona de cizalla de Gastre en 550 la sierra de Calcatapul, provincia de Chubut, Argentina. X Congreso Latinoamericano de Geología 551 y VI Congreso Nacional de Geología Economica, Actas II, 3.

552 Galeazzi, J. S. 1998. Structural and Stratigraphic Evolution of the Western Malvinas Basin, 553 Argentina. AAPG Bulletin, 82(4), 596-636.

554 Hälbich, I. W (ed.). 1993. The Cape Fold Belt-Agulhas Bank Transect across the Gondwana Suture 555 in southern Africa. American Geophysical Union Special Publication, 202, AGU Press, Washington.

556 Hodgkinson, R. 2002. Structural studies in the Falkland Islands, South Atlantic. Unpublished PhD 557 Thesis, University of Birmingham, UK.

558 Hubbard, R.J., Pape, J. \& Roberts, D.G. 1985a. Depositional sequence mapping as a technique to 559 establish tectonic and stratigraphic framework and evaluate hydrocarbon potential on a passive 560 continental margin. In: Berg, O.R. \& Woolverton, D. (eds) Seismic Stratigraphy II: An Integrated 561 Approach to Hydrocarbon Exploration. Am. Assoc. Petrol. Geol., Mem., 39, 79-91.

562 Hubbard, R.J., Pape, J. \& Roberts, D.G. 1985b. Depositional sequence mapping to illustrate the 563 evolution of a passive continental margin. In: Berg, O.R. \& Woolverton, D. (eds) Seismic 564 Stratigraphy II: An Integrated Approach to Hydrocarbon Exploration. Am. Assoc. Petrol. Geol., 565 Mem., 39, 93-115.

566 Ingersoll, R. V., \& Coffey, K. T. 2017. Transrotation Induced by Crustal Blocks Moving through 567 Restraining Double Bends, with Southern California Examples. The Journal of Geology, 125, 551568 559. https://doi.org/10.1086/692654

569 Johnston, S. T. 2000. The Cape Fold Belt and Syntaxis and the rotated Falkland Islands: dextral 570 transpressional tectonics along the southwest margin of Gondwana. Journal of African Earth 571 Sciences, 31(1), 51-63.

572 Kimbell, G. S. \& Richards, P. C. 2008. The three-dimensional lithospheric structure of the Falkland 573 Plateau region based on gravity modelling. Journal of the Geological Society, 165(4), 795-806. 574 https://doi.org/10.1144/0016-76492007-114

575 Lawrence, S. R., Johnson, M., Tubb, S. R. \& Marshallsea, S. J. 1999. Tectono-stratigraphic evolution 576 of the North Falkland region. Geological Society, London, Special Publications, 153(1), 409-424. 577 https://doi.org/10.1144/GSL.SP.1999.153.01.25

578 Lindeque, A., De Wit, M. J., Ryberg, T., Weber, M. \& Chevallier, L. 2011. Deep crustal profile across 579 the Southern Karoo basin and Beattie magnetic anomaly, South Africa: An integrated 580 interpretation with tectonic implications. South African Journal of Geology, 114(3-4), 265-292. 581 https://doi.org/10.2113/gssajg.114.3-4.265

582 Little, T. A. \& Roberts, A. P. 1997. Distribution and magnitude of Neogene to present-day vertical583 axis rotations, Pacific-Australia plate boundary zone, South Island, New Zealand. Journal of 584 Geophysical Research, 102, 20447-20468. 
585

586

587

588

589

590

591

592

593

594

595

596

597

598

599

600

601

602

603

604

605

606

607

608

609

610

611

612

613

614

615

616

617

618

619

620

621

622

623

624

Lohr, T. \& Underhill, J. R. 2015. Role of rift transection and punctuated subsidence in the development of the North Falkland Basin. Petroleum Geoscience, 21(2-3), 85-110. https://doi.org/10.1144/petgeo2014-050

Lorenzo, J. M. \& Mutter, J. C. 1988. Seismic stratigraphy and tectonic evolution of the Falkland/Malvinas Plateau. Revista Brasileira de Geociências, 18(2), 191-200.

Lorenzo, J. M. \& Wessel, P. 1997. Flexure across a continent-ocean fracture zone: the northern Falkland/Malvinas Plateau, South Atlantic. Geo-Marine Letters, 17, 110-118. https://doi.org/10.1007/s003670050015

Ludwig, W. J., Windisch, C. C., Houtz, R. E. \& Ewing, J. I. 1979. Structure of Falkland Plateau and Offshore Tierra del Fuego, Argentina. In: Watkins, J. S., Montadert, L. \& Dickerson, P. W. (eds.) Geological and Geophysical Investigations of Continental Margins, Am. Assoc. Petrol. Geol., Mem., 29, 125-137.

Macdonald, D., Gomez-Perez, I., Franzese, J., Spalletti, L., Lawver, L., Gahagan, L., Dalziel, I., Thomas, C., Trewin, N., Hole, M. \& Paton, D. 2003. Mesozoic break-up of SW Gondwana: implications for regional hydrocarbon potential of the southern South Atlantic. Marine and Petroleum Geology, 20, 287-308.

Marshall, J. E. A. 1994. The Falkland Islands: A key element in Gondwana paleogeography. Tectonics, 13(2), 499-514.

Mascle, J. \& Blarez, E. 1987. Evidence for transform margin evolution from the Ivory Coast-Ghana continental margin. Nature, 326, 378-381.

McCarthy, D., Aldiss, D., Arsenikos, S., Stone, P. \& Richards, P. 2017. Comment on "Geophysical evidence for a large impact structure on the Falkland (Malvinas) Plateau". Terra Nova, 29, 411415.

McMillan, I.K., Brink, G.J., Broad, D.S. \& Maier, J.J., 1997. Late Mesozoic sedimentary basins off the south coast of South Africa. In: Selly, R.C. (ed.) Sedimentary Basins of the World, 3. Elsevier, Amsterdam, 319-376.

Mercier de Lépinay, M., Loncke, L., Basile, C., Roest, W. R., Patriat, M., Maillard, A. \& De Clarens, P. 2016. Transform continental margins - Part 2: A worldwide review. Tectonophysics, 693, 96-115. https://doi.org/10.1016/j.tecto.2016.05.038

Miller, H. G. \& V. Singh. 1994, Potential field tilt-A new concept for location of potential field sources. Journal of Applied Geophysics, 32, 213-217.

Mitchell, C., Taylor, G. K., Cox, K. G. \& Shaw, J. 1986. Are the Falkland Islands a rotated microplate? Nature, 319 (6049), 131-134. https://doi.org/10.1038/319131a0

Mitchell, C., Ellam, R. M. \& Cox, K. G. 1999. Mesozoic dolerite dykes of the Falkland Islands: petrology, petrogenesis and implications for geochemical provinciality in Gondwanaland low-Ti basaltic rocks. Journal of the Geological Society, 156, 901-916.

Mitchum, R.M. Jr., Vail, P.R. \& Sangree, J.B. 1977. Seismic stratigraphy and global changes of sea level; part 6, stratigraphic interpretation of seismic reflection patterns in depositional sequences. In: Payton, C. E. (ed.) Seismic Stratigraphy; Applications to Hydrocarbon Exploration. Am. Assoc. Petrol. Geol., Mem., 26, 117-134. 
625 Moreira, P. \& Fernández, R. R. 2015. La Josefina Au-Ag deposit (Patagonia, Argentina): A Jurassic

626 epithermal deposit formed in a hot spring environment. Ore Geology Reviews, 67, 297-313.

627 Mussett, A. E. \& Taylor, G. K. 1994. 40Ar-39Ar ages for dykes from the Falkland Islands with 628 implications for the break-up of southern Gondwanaland. Journal of the Geological Society, 629 151(1), 79-81. https://doi.org/10.1144/gsjgs.151.1.0079

630 Nguuri, T. K., Gore, J., James, D. E., Webb, S. J., Wright, C., Zengeni, T. G., Gwavava, O., Snoke, J. A. \& 631 Kaapvall Seismic Group. 2001. Crustal structure beneath southern Africa and its implications for 632 the formation and evolution of the Kaapvaal and Zimbabwe cratons. Geophysical Research Letters, 633 28(13), 2501-2504. https://doi.org/10.1029/2000GL012587

634 Oruç, B. \& Keskinsezer, A. 2008. Structural setting of the northeastern Biga Peninsula (Turkey) 635 from tilt derivatives of gravity gradient tensors and magnitude of horizontal gravity components. 636 Pure Appl. Geophys., 165, 1913-1927.

637 Pángaro, F. \& Ramos, V. A. 2012. Paleozoic crustal blocks of onshore and offshore central 638 Argentina: New pieces of the southwestern Gondwana collage and their role in the accretion of 639 Patagonia and the evolution of Mesozoic south Atlantic sedimentary basins. Marine and Petroleum 640 Geology, 37, 162-183.

641 Parsiegla, N., Stankiewicz, J., Gohl, K., Ryberg, T. \& Uenzelmann-Neben, G. 2009. Southern African 642 continental margin: Dynamic processes of a transform margin. Geochemistry, Geophysics, 643 Geosystems, 10(3). https://doi.org/10.1029/2008GC002196

644 Paton, D. A. \& Underhill, J. R. 2004. Role of crustal anisotropy in modifying the structural and 645 sedimentological evolution of extensional basins: The Gamtoos Basin, South Africa. Basin 646 Research, 16(3), 339-359. https://doi.org/10.1111/j.1365-2117.2004.00237.x

647 Paton, D. A. 2006. Influence of crustal heterogeneity on normal fault dimensions and evolution: 648 southern South Africa extensional system. Journal of Structural Geology, 28(5), 868-886.

649 Paton, D. A., Macdonald, D. I. M. \& Underhill, J. R. 2006. Applicability of thin or thick skinned 650 structural models in a region of multiple inversion episodes; southern South Africa. Journal of 651 Structural Geology, 28(11), 1933-1947. https://doi.org/10.1016/j.jsg.2006.07.002

652 Paton, D.A., Mortimer, E.J. \& Hodgson, N. 2016. The missing piece of the South Atlantic jigsaw: 653 when continental break-up ignores crustal heterogeneity. Special Publication of the Geological 654 Society London, 438, 195-210. doi: 10.1144/SP438.8

655 Platt, N. H. \& Philip, P. R. 1995. Structure of the southern Falkland Islands continental shelf: initial 656 results from new seismic data. Marine and Petroleum Geology, 12(7), 759-771.

657 Ramos, V. A. 2008. Patagonia: A Paleozoic continent adrift? Journal of South American Earth 658 Sciences, 26(3), 235-251. https://doi.org/10.1016/j.jsames.2008.06.002

659 Ramos, V. A., Cingolani, C., Junior, F. C., Naipauer, M. \& Rapalini, A. 2017. The Malvinas (Falkland) 660 Islands revisited: The tectonic evolution of southern Gondwana based on U-Pb and Lu-Hf detrital 661 zircon isotopes in the Paleozoic cover. Journal of South American Earth Sciences, 76. 662 https://doi.org/10.1016/j.jsames.2016.12.013

663 Rapela, C. W. \& Pankhurst, R. J. 1992. The granites of northern Patagonia and the Gastre Fault 664 System in relation to the break-up of Gondwana. Geological Society, London, Special Publications, 665 68(1), 209-220. https://doi.org/10.1144/GSL.SP.1992.068.01.13 
666

667

668

669

670

671

672

673

674

675

676

677

678

679

680

681

682

683

684

685

686

687

688

689

690

691

692

693

694

695

696

697

698

699

700

701

702

703

704

705

Reeves, C. V., Teasdale, J. P. \& Mahanjane, E. S. 2016. Insight into the Eastern Margin of Africa from a new tectonic model of the Indian Ocean. Geological Society, London, Special Publications, 431(1), 299-322. https://doi.org/10.1144/SP431.12

Richards, P. C., Gatliff, R. W., Quinn, M. F., Fannin, N. G. T. \& Williamson, J. P. 1996. The geological evolution of the Falkland Islands continental shelf. Geological Society of London Special Publication, 108(1), 105-128. https://doi.org/10.1144/GSL.SP.1996.108.01.08

Richards, P. C. \& Fannin, N. G. T. 1997. Geology of the North Falkland Basin. Journal of Petroleum Geology, 20(2), 165-183. https://doi.org/10.1111/j.1747-5457.1997.tb00771.x

Richards, P. C. \& Hillier, B. V. 2000. Post-drilling analysis of the North Falkland Basin-Part 1: Tectono-stratigraphic framework. Journal of Petroleum Geology, 23(3), 253-272. https://doi.org/10.1111/j.1747-5457.2000.tb01019.x

Richards, P. C., Duncan, I., Phipps, C., Pickering, G., Grzywacz, J., Hoult, R. \& Merritt, J. 2006. Exploring for fan and delta sandstones in the offshore Falklands basins. Journal of Petroleum Geology, 29(3), 199-214.

Richards, P. C., Stone, P., Kimbell, G. S., McIntosh, W. C. \& Phillips, E. R. 2013. Mesozoic magmatism in the Falkland Islands (South Atlantic) and their offshore sedimentary basins. Journal of Petroleum Geology, 36(1), 61-73.

Richardson, J. C., Hodgson, D. M., Paton, D., Craven, B., Rawcliffe, A. \& Lang, A. 2017. Where is my sink? Reconstruction of landscape development in southwestern Africa since the Late Jurassic. Gondwana Research, 45, 43-64. https://doi.org/10.1016/j.gr.2017.01.004

Sandwell, D. T., Müller, R. D, Smith, W. H. F., Garcia, E. \& R. Francis. 2014. New global marine gravity model from CryoSat- 2 and Jason-1 reveals buried tectonic structure. Science, 346(6205), 65-67, doi: 10.1126/science.1258213

Schimschal, C. M. \& Jokat, W. 2017. The crustal structure of the continental margin east of the $\begin{array}{llll}\text { Falkland } & \text { Islands. } & \text { Tectonophysics, } & \text { 724-725, }\end{array}$ https://doi.org/10.1016/j.tecto.2017.11.034

Schreider, A. A., Mazo, E. L., Bulychev, A. A., Schreider, A. A., Gilod, D. A. \& Kulikova, M. P. 2011. The structure of the Falkland Basin's lithosphere. Oceanology, 51(5), 866-875. https://doi.org/10.1134/S0001437011050171

Scrutton, R. A. 1979. On sheared passive continental margins. Tectonophysics, 59, 293-305.

Shone, R.W., Nolte, C.C. \& Booth, P.W.K., 1990. Pre-Cape rocks of the Gamtoos area - a complex tectonostratigraphic package preserved as a horst block. South African Journal of Geology, 93, 616-621.

Soares F., J. R. S., Miranda, A. P. \& de Figueiredo, A. M. F. 2000. Geological and geophysical interpretation of the San Julian basin-offshore Argentina. Geophysical Monograph Series, 115, 193-209. https://doi.org/10.1029/GM115p0193

Stankiewicz, J. \& De Wit, M. 2013. 3.5 billion years of reshaped Moho, southern Africa. Tectonophysics, 609, 675-689. https://doi.org/10.1016/j.tecto.2013.08.033

Stankiewicz, J., Parsiegla, N., Ryberg, T., Gohl, K., Weckmann, U., Trumbull, R. \& Weber, M. 2008. Crustal structure of the southern margin of the African continent: Results from geophysical 

https://doi.org/10.1029/2008JB005612

Stone, P. \& Thomson, M. R. 2005. Archaeocyathan limestone blocks of likely Antarctic origin in Gondwanan tillite from the Falkland Islands. Geological Society, London, Special Publications, 246(1), 347-357. https://doi.org/10.1144/GSL.SP.2005.246.01.14

Stone, P., Richards, P. C., Kimbell, G. S., Esser, R. P. \& Reeves, D. 2008. Cretaceous dykes discovered in the Falkland Islands: implications for regional tectonics in the South Atlantic. Journal of the Geological Society, 165(1), 1-4. https://doi.org/10.1144/0016-76492007-072

Stone, P., Kimbell, G. S. \& Richards, P. C. 2009. Rotation of the Falklands microplate reassessed after recognition of discrete Jurassic and Cretaceous dyke swarms. Petroleum Geosciences, 15(3), 279-287.

Stone, P., Thomson, M. R. A. \& Rushton, A. W. A. 2012. An Early Cambrian archaeocyath-trilobite fauna in limestone erratics from the Upper Carboniferous Fitzroy Tillite Formation, Falkland Islands. Earth and Environmental Science Transactions of the Royal Society of Edinburgh, 102, 201-225.

Stone, P. 2016. Geology reviewed for the Falkland Islands and their offshore sedimentary basins, South Atlantic Ocean. Earth and Environmental Science Transactions of the Royal Society of Edinburgh, 106(2), 115-143. https://doi.org/10.1017/S1755691016000049

Stone, P. 2015. Geological exploration of South Atlantic islands and its contributions to the continental drift debate of the early 20th century. Proceedings of the Geologists' Association, 126(2), 266-281. https://doi.org/10.1016/j.pgeola.2015.01.001

Storey, B. C., Curtis, M. L., Ferris, J. K., Hunter, M. A. \& Livermore, R. A. 1999. Reconstruction and break-out model for the Falkland Islands within Gondwana. Journal of African Earth Sciences, 29(1), 153-163.

Tankard, A.J., Jackson, M.P.A., Eriksson, K.A., Hobday, D.K., Hunter, D.R. \& Minter, W.E.L., 1982. Crustal Evolution of Southern Africa. Spring-Verlag, New York.

Tankard, A., Welsink, H., Aukes, P., Newton, R. \& Stettler, E. 2009. Tectonic evolution of the Cape and Karoo basins of South Africa. Marine and Petroleum Geology, 26(8), 1379-1412. https://doi.org/10.1016/j.marpetgeo.2009.01.022 Seismostratigraphic and structural setting of the Malvinas Basin and its southern margin (Tierra del Fuego Atlantic offshore). Geologica Acta, 6(1), 55-67.

Taylor, G. K. \& Shaw, J. 1989. The Falkland Islands: New palaeomagnetic data and their origin as a displaced terrane from Southern Africa. Deep Structure and Past Kinematics of Accreted Terranes, 50, 59-72.

Thistlewood, L., Leat, P. T., Millar, I. L., Storey, B. C. \& Vaughan, A. P. M. 1997. Basement geology and Palaeozoic-Mesozoic mafic dykes from the Cape Meredith Complex, Falkland Islands: a record of repeated intracontinental extension. Geol. Mag., 134(3), 355-367.

744 Thistlewood, L. \& Randall, D. 1998. Palaeomagnetic studies of West Gondwanan microplates. 745 Journal of African Earth Sciences, 27 (1A: Gondwana 10: Event Stratigraphies of Gondwana 746 (abstracts)), 227. 
Thomas, R.J., Von Veh, M.W., McCourt, S., 1993. The tectonic evolution of southern Africa: an overview. J. Afr. E. Sci., 16, 5-24.

Thomson, K. 1998. When did the Falklands rotate? Marine and Petroleum Geology, 15(8), 723-736

Thomson, K. \& Underhill, J.R. 1999. Frontier exploration in the South Atlantic: structural prospectivity in the North Falkland Basin. AAPG bulletin, 83(5), 778-797.

Tinker, J., de Wit, M. \& Brown, R. 2008. Mesozoic exhumation of the southern Cape, South Africa, quantified using apatite fission track thermochronology. Tectonophysics, 455(1-4), 77-93. https://doi.org/10.1016/j.tecto.2007.10.009

Trewin, N. H., Macdonald, D. I. M. \& Thomas, C. G. C. 2002. Stratigraphy and sedimentology of the Permian of the Falkland Islands; lithostraigraphic and palaeoenvironmental links with South Africa. Journal of the Geological Society of London, 159(1), 5-19. https://doi.org/10.1144/0016764900-089

Trouw, R. A. J. \& De Wit, M. J. 1999. Relation between the Gondwanide Orogen and contemporaneous intracratonic deformation. Journal of African Earth Sciences, 28(1), 203-213. https://doi.org/10.1016/S0899-5362(99)00024-X

Uliana, M. A., Biddle, K. \& Cerdán, J. 1989. Mesozoic extension and the formation of Argentina sedimentary basins. Extensional Tectonics and Stratigraphy of the North Atlantic Margin, AAPG Mem., 46(3), 599-613.

Veevers, J. J., Cole, D. I. \& Cowan, E. J. 1994. Southern Africa: Karoo Basin and Cape Fold Belt. Geological Society of America (Memoir), 184, 223-279. https://doi.org/10.1130/MEM184-p223

Verduzco, B., J. D. Fairhead, C. M. Green \& C. MacKenzie. 2004. The meter reader-New insights into magnetic derivatives for structural mapping. The Leading Edge, 23, 116-119.

Von Gosen, W. 2003. Thrust tectonics in the North Patagonian Massif (Argentina): Implications for a Patagonia plate. Tectonics, 22(1). https://doi.org/10.1029/2001TC901039

Von Gosen, W. \& Loske, W. 2004. Tectonic history of the Calcatapul Formation, Chubut province, Argentina, and the "Gastre fault system." Journal of South American Earth Sciences, 18(1), 73-88. https://doi.org/10.1016/j.jsames.2004.08.007

\section{FIGURE CAPTIONS}

Fig, 1. Present-day configuration and structural framework of the Falkland Plateau; offshore fault network for the Falkland Plateau compiled after Richards et al. (1996), Richards and Fannin (1997), Cunningham et al. (1998), Galeazzi (1998), Tassone et al. (2008) and Ramos et al. (2017); the structure of the San Jorge and El Tranquilo basins and the Deseado Massif redrawn after Fitzgerald et al. (1990), Figari et al. (2015) and Moreira and Fernández (2015); main fracture and subduction zones in South America drawn after Rapela and Pankhurst (1992)

Fig. 2. Map of South Africa and its offshore basins (after Paton et al. 2006; Parsiegla et al. 2009)

Fig. 3. Map of the Falkland Islands (after Aldiss \& Edwards 1999) and their offshore basins (based on Richards et al. 1996); black lines - the position of the 2D seismic reflection lines used in this study, white circles - wells used in this study

Fig. 4. Two models for the palaeogeographic reconstruction of the Falkland Islands - (a) rotational and (b) rigid; (1) - Lawver et al. (1999), (2) - Macdonald et al. (2003), (3) - Trewin et 

pre-break-up ocean - continent boundary; the stratigraphic correlation and colour code are found in Fig. 5

Fig. 5. Lithostratigraphy of the Devonian to Permian deposits of the Falkland Islands and South Africa along with the correlations (dashed lines) presented by Trewin et al. (2002); ages after Curtis and Hyam (1998) and Paton et al. (2006)

Fig. 6. Open-source gravity data (Sandwell et al. 2014) and the $1^{\text {st }}$ vertical, total horizontal and tilt derivatives for offshore Falkland Islands; gravity lineaments (stippled lines) interpreted based on the computed derivatives are superimposed on the free air gravity anomaly; rectangle shows the extent of the map in Fig. 7

Fig. 7. Normal faults interpreted based on seismic reflection data in the SNFB superimposed on the TWT map of the mega-décollement; the faults are following the same orientation as the NWSE gravity lineaments mapped across the SNFB; grey line network represent the seismic reflection profiles used for interpretation

Fig. 8. Compilation of seismic sections across Fault B from west (a) to east (i) showing how the geometry of the syn-rift package varies along the fault; position of the lines is shown in Fig. 7 (8a $-8 \mathrm{j})$

Fig. 9. Sections across E-W trending features associated with (a) fracture zones generating structural lows and (b) half-grabens; sedimentary packages showing slight thickening into faults are shaded in grey; position of the lines is shown in Fig. 7

807 Fig. 10. Seismic sections showing: (a), (b) the morphology of the shallower set of deep reflectors interpreted as a mega-décollement; (c), (d) the extent of the second set of deep reflectors correlated with Moho; (e) line drawing and interpretation of section in (b) showing the interaction between the reactivated thrust faults mapped across the SNFB and the megadécollement along with their common sense of vergence; (f) line drawing and interpretation of section in (c) showing a potential merging between the mega-décollement and the Moho discontinuity; location of the profiles is shown in Fig. 7

814 Fig. 11. (a) Depth converted section across the SNFB extrapolated onshore based on published

815 data from Aldiss \& Edwards (1999) and Stone (2016); (b) section across the South African margin 816 and its offshore basins showing the steepening of the faults south-westwards (after Paton et al. 817 2006); stippled rectangle shows the extent of the South African equivalent of the section in (a). 818 Both sections are restored to the top syn-rift

819 Fig. 12. Revised position of the Falkland Islands microplate at 180 Ma. The mega-décollement 820 in South Africa is constrained by two seismic lines: (1) (Dürrheim 1987) and (2) (Lindeque et al. 821 2011) and extrapolated until it intersected Moho as modelled by Nguuri et al. (2001) and 822 Stankiewicz \& de Wit (2013); mega-décollement inferred on profile (3) (Paton et al. 2006) is used 823 for comparison and validation. The mega-décollement underneath the SNFB was truncated at 824 depths of 30-35 km (based on this study, Kimbell \& Richards (2008) and Schimschal \& Jokat 825 (2017)). Faults in the Outeniqua Basin are drawn based on Paton et al. (2006) and Parsiegla et al. 826 (2009); GF - Gamtoos Fault, PEF - Port Elizabeth Fault, SCF - St. Croix Fault. Faults in the SNFB are drawn based on the seismic reflection (grey lines) and gravity data available for this study; faults onshore Eastern Falkland are based on Aldiss \& Edwards (1999); the position of the section in Fig. 11a is shown onshore and offshore the Falkland Islands 